\title{
Gender and health inequalities among adolescents and adults in Brazil, 1998
}

\author{
Rita Barradas Barata, ${ }^{1}$ Márcia Furquim de Almeida, ${ }^{2}$ \\ Cláudia Valencia Montero, ${ }^{3}$ and Zilda Pereira da Silva ${ }^{4}$
}

Suggested citation Barata RB, Almeida MF, Montero CV, Silva ZP. Gender and health inequalities among adolescents and adults in Brazil, 1998. Rev Panam Salud Publica. 2007;21(5):320-7.

ABSTRACT Objectives. To assess the extent of gender inequalities in health status and health services utilization among adolescents and adults in Brazil.

Methods. A representative sample of 217248 individuals from 15 to 64 years of age was obtained from the National Household Sample Survey (Pesquisa Nacional de Amostras por Domicílios, PNAD) conducted in 1998 by the Brazilian Institute of Geography and Statistics and funded by the Ministry of Health. The study focused on three outcome variables (selfassessed health status, medical visits, and hospitalizations (except childbirth)) and five exposure variables (age, gender, ethnicity, income, and education). Unconditional logistic regression and Mantel-Haenszel stratified analysis was employed. Prevalence rate ratios were calculated for each stratum. Confidence intervals were calculated using the Taylor series, with a $95 \%$ confidence interval $(95 \%$ CI).

Results. Women were more likely to report fair or poor health than men (odds ratio $(O R)=$ 1.33; 95\% CI: 1.31-1.35). Gender disparities were significant for all ages, household income brackets, and education levels, and were always unfavorable to women $(1.17 \leq O R \leq 1.44)$. Gender disparities for medical visits were higher for those in good health; tended to fall as age, income, and education increased; and were always favorable for women $(1.12 \leq \mathrm{OR} \leq 2.06)$. Gender disparities in hospitalization rates decreased with age, varied according to income and education level in each age group, and were always favorable for women $(1.16 \leq \mathrm{OR} \leq 1.66)$. Conclusions. The difference in self-reported health status for men and women became even greater after adjusting for socioeconomic variables, suggesting that poorer women have more pronounced, relative differences than men do. The impact of structural determinants, such as education and income, is considerably smaller than the social construct of gender, although the former are more important predictors. Women use health services more often than men do, which is consistent with their health needs. However, medical visit rates show an inverse relationship to health care needs, suggesting an inequitable access to outpatient care, mainly preventive care.

Key words Women's health, health behavior, health services accessibility, health services/ utilization, health status, Brazil.

\footnotetext{
Social Medicine Department, Santa Casa de São Paulo Medical School, São Paulo, Brazil. Send correspondence to: Rita Barradas Barata, Rua Dr. Cesário Motta Jr. 61, $6^{\circ}$ andar, São Paulo SP, Brasil, 01221-020; telephone: 55-11-3367-7770; fax: 55-11-3222-3812; e-mail: rita.barata@fcmscsp. edu.br.
}

2 Epidemiology Department, University of São Paulo School of Public Health, São Paulo, Brazil.

3 Disease Surveillance Center "Prof. Alexandre Vranjac" and São Paulo State Health Department, São Paulo, Brazil.

4 Data Analysis State Foundation-SEADE, São Paulo, Brazil
The "right to health" concept is the foundation for social policies in which equity is a core element (1). Health "inequities," it must be noted, differ from "inequalities." Braveman and Gruskin 
(2) defined "inequity" in health as "systematic disparities in health between social groups who have different ... positions in a social hierarchy"; whereas, "inequality" is used for "differences that are not necessarily unfair or unjust." Many Western countries, particularly those of the European Union and the Region of the Americas, have national health policies that aim to reduce health inequities $(3,4)$.

The right to health has two main components. One is the health-disease process determined by societal hierarchies. The second is society's response to health problems and needs. The health-disease process is complex. There are different levels of determinants for each dimension of the social construct. Structural determinants, those related to social development and the individual's position in the social organization, have greater explanatory value for health status.

The equitable distribution of health services and activities has three important components: access, utilization, and quality (1). Health services utilization has a set of determinants that includes a health need or problem that results in the individual's demand for services. There is a series of predisposing factors that change the perception of health needs, and, therefore, play a decisive role in making service demands concrete. These predisposing factors include age, gender, ethnicity, and socioeconomic conditions. Given a demand, service utilization will depend on the availability of services and human resources, ease of access, forms of funding, and payment of providers $(5,6)$.

There are many factors present in the health status and behavior framework. Age, gender, and ethnicity are major biological characteristics that determine health problems. In addition, socioeconomic, cultural, and political factors produce different perspectives of health and specific circumstances that may affect health status, even among individuals who share the same biological characteristics. All these factors interact in a system with multiple levels that include cultural beliefs, distribution of power and property, and interaction and aspects of individual identity (7). Ethnic and gender disparities have historically been attributed to either biological factors (race or sex-related theories) or socioeconomic factors (economicsdriven theories). However, the impact of social advantages and disadvantages on health is not fully understood. Men and women markedly differ in social roles, both in the family and the job market (8).

The structural adjustment policies of the 1980s contributed to increasing inequality in the living conditions of the populations of indebted countries. The process of wealth concentration increased in the 1990s, and some countries were forced to start charging for the utilization of health services, thereby also increasing inequalities in access (9). A new national health system was established in late 1980 in Brazil, creating universal, integrated, and equitable access and utilization of health services as a means for guaranteeing the right to health, as mandated by the new federal constitution.

Access to health services is considered a right of all citizens in Brazil, regardless of their social security contributions, as it had been before the 1970s. However, health inequalities remain as a result of disparate living conditions and lack of service availability. This paper aims to analyze inequalities in health status and health services utilization in the population 15-64 years of age, according to gender, after stratification by age and socioeconomic brackets.

\section{METHODS}

The data used in this analysis were compiled as part of a health supplement to the National Household Sample Survey (Pesquisa Nacional de Amostra por Domicílios (PNAD)) conducted in 1998 by the Brazilian Institute of Geography and Statistics, with funds from the Ministry of Health. The sample, obtained in multiple stages, provides representative information for the Brazilian population, except for the rural population of the Northern region. The survey included 221088 individuals from 15 to 64 years of age; however, 217248 individuals were included in this analysis, following a loss of $2 \%$ from the initial sample due to lack of information about one or more variables of interest. Additional sample details and statistical procedures for data analysis are available in Silva et al. (10). This study used three outcome variables and four predisposing variables. The three outcome variables were: (1) self-assessment of health status, rated as "poor," "fair," or "good"; (2) number of medical office visits during the 12 months preceding the interview; and (3) number of hospitalizations, excluding birth-related stays, during the same timeframe. The five exposure variables were: (1) age, grouped by "youth" (15-24 years of age), "young adult" (25-44 years), and "adult" (45-64 years); (2) gender; (3) household income (measured as the family's monthly consumptioncapacity based on a multiple of the monthly household minimum wage); (4) social status (measured in terms of the number of years of formal education); and (5) ethnicity (self-defined and categorized as "white" or "black," including all different self-reported ethnic groups).

Regarding the outcome variable "self-assessment of health status," it is important to note that perceived health eventually influences the quality of everyday life, and consequently, the demand for health services. A number of longitudinal studies have shown that self-assessment is a reliable predictor for the risk of death, even after controlling for age, gender, social status, and objective health conditions (11).

The rate of medical office visits was calculated by the proportion of individuals with at least one visit in the preceding 12 months, divided by the total number of individuals in each age, gender, household income, education, and ethnicity group. The hospitalization rate was determined in the same way, and as mentioned, excluded birth-related hospital admissions.

Unconditional logistic regression was used to assess the contribution of each independent variable to health 
status. Since all the variables showed significant associations with the outcomes in the univariate analysis, they were all included in the model.

Given that the population's health status and health services utilization result from a set of interrelated variables whose total effect may be greater than the sum of the independent factors, adjustment models may have hidden some important aspects. In addition, the impact of these variables may differ among the strata. These effects are difficult to identify in regression models. Stratification can help disassociate related processes without the need to resort to a large number of assumptions (8).

Prevalence rate ratios were calculated for each stratum, and for the whole, using the Mantel-Haenszel procedure. Confidence intervals were calculated using the Taylor series, with a $95 \%$ confidence interval (95\% CI). Two software programs were used for data processing: EPI-INFO 6.10 (Centers for Disease Control and Prevention, Atlanta, Georgia, United States of America) and the Statistical Package for the Social Sciences 11.0 (SPSS Inc., Chicago, Illinois, United States).

Given that socioeconomic disadvantages may explain, to a great extent, health status and health services consumption patterns, the authors chose to control for the effect of monthly household income and level of education. These were used as indirect indicators of social conditions that may influence outcomes, in an attempt to highlight the mediating effect of these variables on gender-related inequalities in health $(12,13)$.

\section{RESULTS}

\section{Health status}

Among interviewees, $4.9 \%$ selfassessed their health as "poor," $21.8 \%$ considered it "fair," and 73.3\% rated it "good." Women were more likely to report fair or poor health status than were men (odds ratio $(\mathrm{OR})=1.33$; 95\% CI: 1.31-1.35). Prevalence of fair or poor health was associated with the

TABLE 1. Prevalence of fair or poor health status according to sociodemographic variables, Brazil, 1998

\begin{tabular}{|c|c|c|c|}
\hline Variables & $\begin{array}{l}\text { Prevalence of fair/poor } \\
\text { health status }\end{array}$ & $\begin{array}{l}\text { Prevalence } \\
\text { rate ratio }\end{array}$ & $95 \% \mathrm{Cl}$ \\
\hline \multicolumn{4}{|l|}{ Age } \\
\hline $15-24$ & 11.00 & 1.00 & \\
\hline $25-44$ & 21.30 & 1.94 & $1.89-1.99$ \\
\hline $45-64$ & 44.26 & 4.03 & $3.93-4.12$ \\
\hline \multicolumn{4}{|l|}{ Gender } \\
\hline Male & 19.78 & 1.00 & \\
\hline Female & 26.87 & 1.36 & $1.34-1.38$ \\
\hline \multicolumn{4}{|l|}{ Ethnicity } \\
\hline White & 20.89 & 1.00 & \\
\hline Black & 26.31 & 1.26 & $1.24-1.28$ \\
\hline \multicolumn{4}{|l|}{ Education } \\
\hline$\leq 3$ years & 38.34 & 3.05 & $2.97-3.13$ \\
\hline $4-7$ years & 23.94 & 1.90 & $1.85-1.95$ \\
\hline $8-10$ years & 15.80 & 1.26 & $1.21-1.30$ \\
\hline $11+$ years & 12.58 & 1.00 & \\
\hline \multicolumn{4}{|c|}{ Household income (MMW)a } \\
\hline$<3$ & 31.57 & 1.92 & $1.88-1.95$ \\
\hline $3-5$ & 24.67 & 1.50 & $1.47-1.53$ \\
\hline$>5$ & 16.48 & 1.00 & \\
\hline
\end{tabular}

a $\mathrm{MMW}=$ monthly minimum wage.

predisposing variables in the following ways: it increased with age, was higher among women and individuals of African descent, and fell as education and income levels rose (Table 1).

OR estimates adjusted in the regression model are presented in Table 2 . The variables are presented according to the order of entrance into the model. In this step, the results were first adjusted by age, second by ethnicity, third by education, and fourth by income. Reference categories were: individuals 15-24 years old, white males, education of 11 years or more, and monthly household income more than five times the monthly minimum wage. The model with all sociodemographic variables has a limited predictive capability, although the adjustment is significant (pseudo- $R^{2}=11.45 \%$ ).

The highest odds ratios (OR $\geq 2.00)$ were observed among adults (4564 years of age), less than 4 years of schooling (functionally illiterate), young adults (25-44 years of age), and 4-7 years of schooling.

Intermediate odds ratios $(1.50<$ OR < 2.00) were observed for households with income less than three times the monthly minimum wage, for women, and for individuals with 8-10 years of schooling.

The lowest odds ratios $(\mathrm{OR}<1.50)$ were observed for households with income 3-5 times the monthly minimum wage and for individuals of African descent.

The prevalence of fair or poor health status, according to age group and gender and stratified by household income brackets, increases with age in all income brackets and falls as income rises (Table 3 ). The differentials according to gender remained statistically significant for all brackets, thus demonstrating that there are inequalities regardless of income.

In the youth group, the smallest relative difference (roughly 19\%) was among those with monthly household income one to two times the monthly minimum wage. In the other income brackets, the relative difference is similar, remaining around $34 \%$ to $41 \%$.

In the young adult and adult groups, the smallest relative differences are observed in the lowest income brackets, with similar values in the remaining income brackets (Table 3 ). The differentials tend to be smaller in the adult group, 45-64 years of age. 
TABLE 2. Crude and adjusted odds ratio and $95 \%$ confidence interval (Cl) for fair/poor health status, Brazil, 1998

\begin{tabular}{|c|c|c|c|c|c|c|c|c|c|c|}
\hline \multirow[b]{2}{*}{ Variables } & \multicolumn{2}{|c|}{$\begin{array}{l}\text { Initial } \\
\text { model }\end{array}$} & \multicolumn{2}{|c|}{$\begin{array}{l}\text { Model } 1 \\
\text { (includes } \\
\text { age) }\end{array}$} & \multicolumn{2}{|c|}{$\begin{array}{c}\text { Model } 2 \\
\text { (includes } \\
\text { ethnicity) }\end{array}$} & \multicolumn{2}{|c|}{$\begin{array}{c}\text { Model } 3 \\
\text { (includes } \\
\text { education) }\end{array}$} & \multicolumn{2}{|c|}{$\begin{array}{c}\text { Final model } \\
\text { (includes } \\
\text { income) }\end{array}$} \\
\hline & $\mathrm{COR}^{\mathrm{a}}$ & $\mathrm{Cl} 95 \%$ & $\mathrm{AOR}^{\mathrm{b}}$ & $95 \% \mathrm{Cl}$ & $\mathrm{AOR}^{\mathrm{b}}$ & $95 \% \mathrm{Cl}$ & $\mathrm{AOR}^{\mathrm{b}}$ & $95 \% \mathrm{Cl}$ & $\mathrm{AOR}^{\mathrm{b}}$ & $95 \% \mathrm{Cl}$ \\
\hline \multicolumn{11}{|l|}{ Gender } \\
\hline Male & 1.00 & & 1.00 & & 1.00 & & 1.00 & & 1.00 & \\
\hline Female & 1.49 & $1.47-1.53$ & 1.51 & $1.47-1.54$ & 1.52 & $1.49-1.52$ & 1.58 & $1.55-1.62$ & 1.57 & $1.53-1.60$ \\
\hline \multicolumn{11}{|l|}{ Age (years) } \\
\hline $15-24$ & 1.00 & & 1.00 & & 1.00 & & 1.00 & & 1.00 & \\
\hline $25-44$ & 1.94 & $1.89-1.99$ & 2.14 & $2.08-2.20$ & 2.19 & $2.13-2.26$ & 2.23 & $2.17-2.30$ & 2.22 & $2.16-2.29$ \\
\hline $45-64$ & 4.03 & $3.93-4.12$ & 6.36 & $6.17-6.55$ & 6.67 & $6.47-6.87$ & 5.77 & $5.60-5.96$ & 6.15 & $5.95-6.35$ \\
\hline \multicolumn{11}{|l|}{ Ethnicity } \\
\hline White & 1.00 & & & & 1.00 & & 1.00 & & 1.00 & \\
\hline Black & 1.26 & $1.24-1.28$ & & & 1.53 & $1.50-1.56$ & 1.25 & $1.22-1.27$ & 1.18 & $1.16-1.21$ \\
\hline \multicolumn{11}{|l|}{ Education (years) } \\
\hline 11 and more & 1.00 & & & & & & 1.00 & & 1.00 & \\
\hline $8-10$ & 1.26 & $1.21-1.30$ & & & & & 1.71 & $1.64-1.78$ & 1.54 & $1.48-1.60$ \\
\hline $4-7$ & 1.90 & $1.85-1.95$ & & & & & 2.41 & $2.33-2.49$ & 2.00 & $1.93-2.07$ \\
\hline $0-3$ & 3.05 & $2.97-3.13$ & & & & & 3.57 & $3.45-3.69$ & 2.73 & $2.63-2.83$ \\
\hline \multicolumn{11}{|l|}{ Income ${ }^{c}$} \\
\hline$>5$ & 1.00 & & & & & & & & 1.00 & \\
\hline $3-5$ & 1.50 & $1.47-1.53$ & & & & & & & 1.40 & $1.37-1.45$ \\
\hline $0-2$ & 1.92 & $1.88-1.95$ & & & & & & & 1.68 & $1.63-1.73$ \\
\hline
\end{tabular}

a $\mathrm{COR}=$ crude odds ratio.

${ }^{\mathrm{b}} \mathrm{AOR}=$ adjusted odds ratio.

${ }^{c}$ monthly household income is expressed as a multiple of monthly minimum wage.

TABLE 3. Prevalence of fair or poor health status according to age, household income level, and gender, Brazil,1998

\begin{tabular}{|c|c|c|c|c|c|c|c|c|c|c|}
\hline \multirow{2}{*}{$\begin{array}{c}\text { Household } \\
\text { income (MMW) }\end{array}$} & \multirow[b]{2}{*}{ Gender } & \multicolumn{3}{|c|}{$15-24$ years } & \multicolumn{3}{|c|}{$25-44$ years } & \multicolumn{3}{|c|}{$45-64$ years } \\
\hline & & Prevalence & $\mathrm{PRR}^{\mathrm{b}}$ & $95 \% \mathrm{Cl}^{\mathrm{c}}$ & Prevalence & $\mathrm{PRR}^{\mathrm{b}}$ & $95 \% \mathrm{Cl}$ & Prevalence & $\mathrm{PRR}^{\mathrm{b}}$ & $95 \% \mathrm{Cl}$ \\
\hline$<1$ & $\begin{array}{l}\text { Female } \\
\text { Male }\end{array}$ & $\begin{array}{l}16.82 \\
12.53\end{array}$ & 1.34 & $1.20-1.50$ & $\begin{array}{l}33.69 \\
28.34\end{array}$ & 1.19 & $1.12-1.26$ & $\begin{array}{l}64.12 \\
54.72\end{array}$ & 1.17 & $1.12-1.23$ \\
\hline $1-2$ & $\begin{array}{l}\text { Female } \\
\text { Male }\end{array}$ & $\begin{array}{l}16.69 \\
14.02\end{array}$ & 1.19 & $1.08-1.31$ & $\begin{array}{l}31.84 \\
23.98\end{array}$ & 1.33 & $1.26-1.40$ & $\begin{array}{l}62.27 \\
48.36\end{array}$ & 1.29 & $1.23-1.35$ \\
\hline$>5$ & $\begin{array}{l}\text { Female } \\
\text { Male }\end{array}$ & $\begin{array}{l}9.00 \\
6.38\end{array}$ & 1.41 & $1.30-1.53$ & $\begin{array}{l}16.43 \\
12.09\end{array}$ & 1.36 & $1.30-1.43$ & $\begin{array}{l}37.74 \\
29.36\end{array}$ & 1.29 & $1.24-1.33$ \\
\hline
\end{tabular}

${ }^{\text {a }} \mathrm{MMW}=$ monthly minimum wage.

b $\mathrm{PRR}=$ prevalence rate ratio.

${ }^{\mathrm{C}} \mathrm{Cl}=$ confidence interval .

The stratified analysis by level of education shows results similar to those obtained through household income stratification (data not presented). The relative differences tend to fall with increase in age and are relatively similar among the levels of education, again showing the independence of the gender variable.

\section{Health services utilization}

The rate of medical visits in the 12 months preceding the survey was 1.63 times higher among women (95\% CI:1.60-1.66) than among men; and hospitalization rates, excluding birthrelated admissions, were 1.39 times (95\% CI:1.28-1.52) more frequent for women.
Medical visits. The rates of medical visits were higher for women than men at all income levels, regardless of their reported health status (Table 4). The rate of medical visits for both men and women increased proportionately with household income, with a progressive reduction in the relative inequality between the 
TABLE 4. Medical visits rate according to age group, health status, monthly household income, and gender, Brazil, 1998

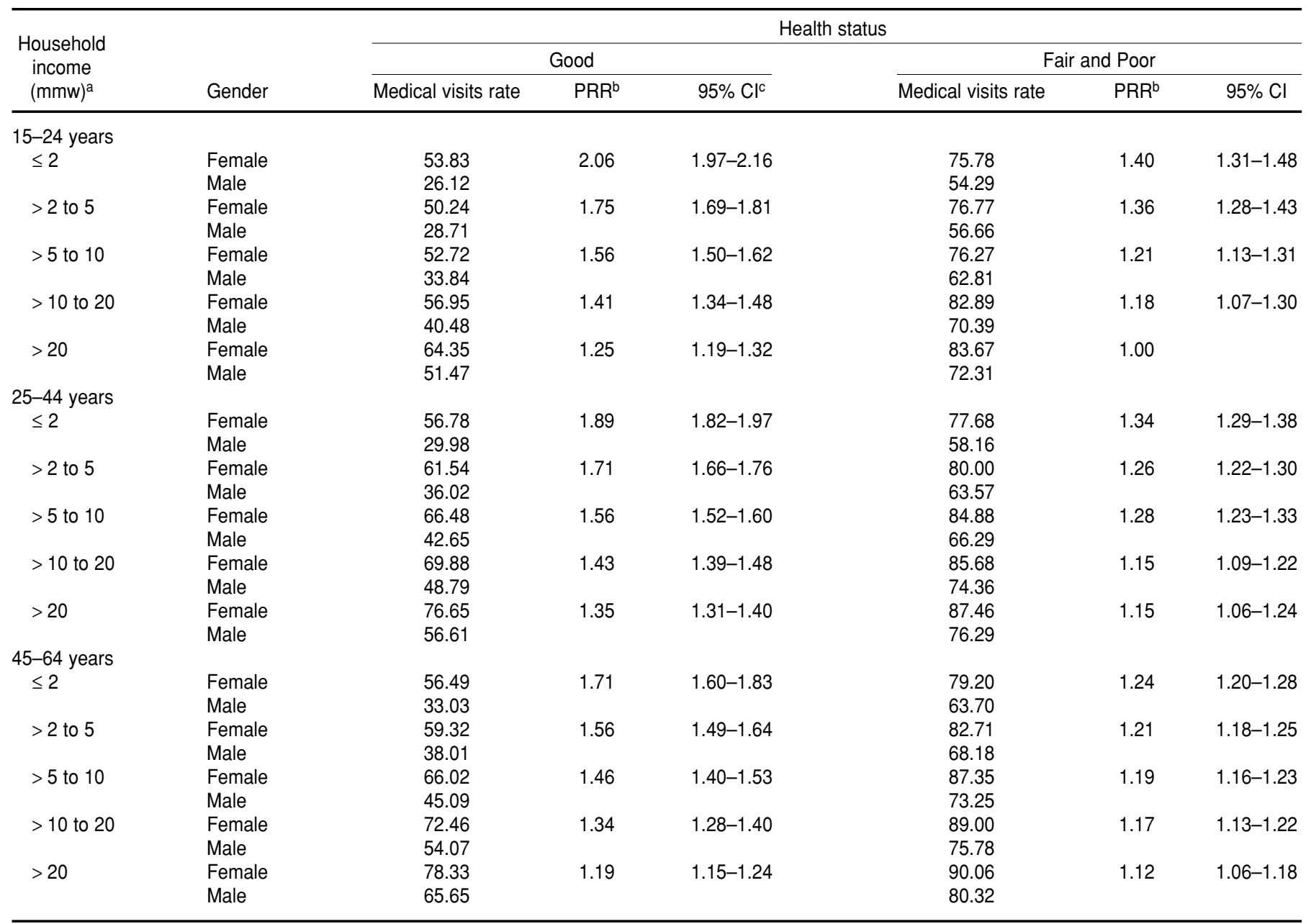

a MMW = monthly minimum wage.

${ }^{b} \mathrm{PRR}=$ prevalence rate ratio.

${ }^{\mathrm{C}} \mathrm{Cl}=$ confidence interval.

genders as income bracket and age increase.

The most pronounced gender inequality regarding medical visits was observed among adolescents with good health status and household income up to twice the minimum wage. In addition, the stratified analysis showed greater inequality of gender in all age groups when health status was considered good. The gender gap among those with fair or poor health status was smaller between household income brackets for all age groups and tended to disappear for those in the higher income brackets.

The rate of medical visits, stratified by education, increases with age and edu- cation for both genders. Gender inequality is more pronounced among youth (15-24 years) regarding medical visits, and is greater among those with fewer years of education and good health (data not presented). For individuals reporting fair or poor health, education does not impact gender inequalities.

Hospitalization rates. For both men and woman, hospitalization rates, excluding those related to childbirth, increased with age and tended to fall slightly with rising household income. Gender inequalities in hospitalization rates among youth (15-24 years of age) were similar for all household income brackets, with the exception of the group with income more than five times the monthly minimum wage, in which the difference fell significantly. Point estimates suggest an inversely proportional gradient between gender inequality and average household income, although confidence intervals overlap. The absence of statistical significance may be due to the small sample size, given that the frequency of hospitalizations in this age group was relatively low.

In the young adult group (25-44 years of age), gender differentials can be seen in all household income brackets, with prevalence rate ratios ranging between 1.33 and 1.50. The differences between prevalence rate ratios are not 
TABLE 5. Hospitalization rate in the previous year according to age, household income, and gender, Brazil, 1998.

\begin{tabular}{|c|c|c|c|c|c|c|c|c|c|c|}
\hline \multirow[b]{2}{*}{$\begin{array}{l}\text { Household } \\
\text { income (MMW) }\end{array}$} & \multirow[b]{2}{*}{ Gender } & \multicolumn{3}{|c|}{$15-24$ years } & \multicolumn{3}{|c|}{ 25-44 years } & \multicolumn{3}{|c|}{ 45-64 years } \\
\hline & & $\begin{array}{l}\text { Hospitalization } \\
\text { rate }\end{array}$ & $\mathrm{PRR}^{\mathrm{b}}$ & $95 \% \mathrm{Cl}^{\mathrm{c}}$ & $\begin{array}{l}\text { Hospitalization } \\
\text { rate }\end{array}$ & $\mathrm{PRR}^{\mathrm{b}}$ & $95 \% \mathrm{Cl}$ & $\begin{array}{l}\text { Hospitalization } \\
\text { rate }\end{array}$ & $\mathrm{PRR}^{\mathrm{b}}$ & $95 \% \mathrm{Cl}$ \\
\hline $1-2$ & $\begin{array}{l}\text { Female } \\
\text { Male }\end{array}$ & $\begin{array}{l}5.01 \\
3.02\end{array}$ & 1.66 & $1.35-2.03$ & $\begin{array}{l}7.06 \\
4.70\end{array}$ & 1.50 & $1.31-1.72$ & $\begin{array}{c}10.23 \\
9.04\end{array}$ & 1.00 & \\
\hline$>5$ & $\begin{array}{l}\text { Female } \\
\text { Male }\end{array}$ & $\begin{array}{l}3.07 \\
2.64\end{array}$ & 1.16 & $1.01-1.34$ & $\begin{array}{l}5.64 \\
3.85\end{array}$ & 1.46 & $1.34-1.60$ & $\begin{array}{l}8.47 \\
6.60\end{array}$ & 1.28 & $1.17-1.40$ \\
\hline
\end{tabular}

${ }^{\text {a }} \mathrm{MMW}=$ monthly minimum wage.

b $\mathrm{PRR}=$ prevalence rate ratio

${ }^{\mathrm{C}} \mathrm{Cl}=$ confidence interval.

significant, suggesting that gender inequality remains, regardless of average household income (Table 5).

Among adults (45-64 years of age), gender inequality is observed in hospitalization rates when the household income is more than twice the monthly minimum wage, but these differences are smaller than those observed in the other age groups (Table 5).

Hospitalization rates stratified by education levels showed a similar trend to that observed for household income (data not presented). For gender differentials, the highest rate ratios are observed in the young adult group (25-44 years of age), with no significant differences for different levels of education. For adults, there is a marked difference in the hospitalization rates of women with 8-10 years of education, and among adolescents for females with 4-7 years of education (data not presented).

Therefore, gender inequality is present in all of the demographic (age and gender) and socioeconomic (income and education) groups studied.

\section{DISCUSSION}

The inequalities found in selfassessed health status indicate that women tend to consider their health to be worse than that of men; however, the inequalities in health services utilization indicate that women seek medical attention more frequently, consistent with their perceived health status.

These results concurred with those of several other studies. Gender inequality in the presence of fair or poor health status was also observed regarding chronic conditions, restriction of activities (7), and demand for health services $(5,6,14)$. Romero, who analyzed the same database for the elderly population, found a higher incidence of women reporting poor health status, even after controlling for age, socioeconomic bracket, and family structure (15). Krasnik (1) found more pronounced differences in the Danish population, with women reporting health status as fair or poor 1.8 times more often than men. Denton and Walters (16), when analyzing the data of Canada's national health survey, found that most of the variations in the health status of men and women were explained by structural determinants (19.2\% and $19.5 \%$, respectively), rather than by behavioral ones $(15.0 \%$ and $10.9 \%$, respectively).

These data reinforce the concept of gender as a social construct, which determines how men and women experience life events differently within the same context. In other words, the impact of structural determinants (e.g., education, income) is considerably smaller than behavioral determinants (gender), although the former can be more important predictors of health status. The difference between men and women, regarding their health status, became even greater after adjusting for socioeconomic variables, suggesting that poorer women have more pronounced relative differences than men do. Age is also an important factor after controlling for other variables, as is education (except for the functionally illiterate). Both household income and ethnicity partially lose their explanatory capacity after controlling for other variables, although they remain significant.

The persistence of gender differences regarding health status-even after stratification for household income or education-underscores the assumption that structural determinants do not fully account for these differences, although they may play a modulating role. Men and women play significantly different social roles within the family and society as a whole (8). Different societies may also produce different degrees of inequality between men and women (12). In addition, within a single society, gender inequalities in the self-assessed health status may vary among ethnic groups and social classes $(8,17,18)$. The United States National Health Survey data for the period from 1986 to 1995 , analyzed by Case and Deaton (12), show that until 65 years of age, women report worse health than men do, with the difference between them disappearing after that age, when the 
proportion of individuals with fair or poor health reaches higher values. Data referring to the population of South Africa show that its population behaves similarly, although with greater prevalence of fair or poor health at all ages. Case and Deaton (12) also mention that Sadana and his team, in a technical report prepared for the World Health Organization, analyzed 64 different countries and found that the health status among women was evaluated as poor in 46 of those countries.

Considering that health needs are the main determinant of health services utilization, and that women perceive their health to be poor or fair more often then men, their higher frequency of utilization could be explained by this greater perceived need. However, the gender difference in utilization rates is actually more pronounced for those with good health, as opposed to those with fair or poor health. Other studies have also shown that the average number of medical visits per year is higher for women, and that women make proportionally more visits for prevention or routine tests, and fewer medical visits due to disease than do men $(8,19,20)$. The rates of medical visits show a pattern that is inverse to health care needs in the different socioeconomic brackets, suggesting an inequitable pattern of access to outpatient care. Part of this difference in utilization, however, results from the greater use of preventive medical visits by higher social brackets, showing a greater concern with health and avoiding health issues through preventive measures (21).

Other determinants of medical office visit rates in different populations stand out, such as health insurance coverage, physical accessibility, and defining a regularly used professional health care facility $(8,21)$. The data from the PNAD, on which the present study was based, does not provide information on variables such as physical accessibility or regularly used health care facility. These, as well as health insurance coverage, are strongly associated with higher income and education brackets, and consequently im- pact health status. Although, these aspects may have an influence on health services utilization, they are not as significant as health needs are to determining utilization.

Regarding hospitalization, rates increased with age (as health status deteriorates) and decreased in higher income brackets and with years of education in all age groups, in accordance with health status. The hospitalization rate for the Brazilian population was similar to that reported by Parkerson (19) for the population of the state of North Carolina, in the United States. Gender differences are more pronounced among younger persons and tend to fall as age increases, increasing parity, in a manner similar to that observed for health status. Therefore, in the case of hospitalizations, the health system seems to provide greater equity. Utilization rates are distributed according to health status, suggesting that the leading determinant of utilization is health need. Travassos and colleagues (22), analyzing the 1986 PNAD data, but using another health indicator and another measurement of health care utilization, found similar gender- and age-related differences. Aquino et al. (23) found similar gender- and agerelated differences in health service utilization and health care demands.

Gender inequalities in health status and utilization result from the complex interaction of several determinants, including biological factors, emotional components related to the reproduction, and the cultural factors related to the division of power in society (24). Our results corroborate Krieger's findings (25) showing that both sex (a biological construct) and gender (a social construct) do matter.

In order to account for the complexity of the determinants for the health services utilization, Mendonza-Sassi and Béria (21) propose a four-level hierarchical model, in which the first and most distal level corresponds to socioeconomic and demographic determinants; the second level is comprised of family strategies, social support, and health-stressing events present in every day life; the third level is formed by behavior when seeking care, features of service supply, and health needs; and the fourth, and most proximal level, is defined by the satisfaction or previous experience individuals had with utilization of services. The analyses of the present study are limited to the most distal level, that of socioeconomic and demographic determinants, which only partly account for determinations, as evidenced by the small predictive power of the adjustment model.

Gender, as a social construct, is a multilevel system that includes economic and political circumstances and cultural beliefs at the macro level, behavior at the intermediary level, and aspects related to individual identity at the micro level. This multidimensional structure translates into individuals with identities of men and women, engaged in several family and social roles (7). From this perspective, social capital is understood as a resource inherent to relationships between people or organizations. It refers to the resources that people develop in their personal experiences through daily interactions establishing connections between concrete actions of everyday life and broader collective and social structures (9).

Gender equity in health does not imply equality between men and women, either in their health status or in the consumption of health care services. Rather, gender equity means equitably meeting the needs of men and women, inasmuch as the higher utilization rate by women follows their health status and a greater awareness of their health. Socioeconomic differences associated with or independent of the gender-related features remain in spite of the universal character of the Brazilian health system. On the other hand, further research is needed, such as on how much the existence of health policies centered chiefly on women's reproductive health might be influencing their higher utilization rate.

Acknowledgments: This study was funded by the Ministry of Health of Brazil. Data were obtained from its records. 


\section{REFERENCES}

1. Krasnik A, Hansen E, Keiding N, Sawitz A. Determinants of general practice utilization in Denmark. Dan Med Bull. 1997;44:556-60.

2. Braveman P, Gruskin S. Defining equity in health. J Epidemiol Community Health. 2003; 57:254-8.

3. Anitua C, Esnaola S. Changes in social inequalities in health in the Basque Country. J Epidemiol Community Health. 2000;54: 437-43.

4. Tugwell P, O'Connor A, Andersson N, Mhatre S, Kristjansson E, Jacobsen MJ, et al. Reduction of inequalities in health: assessing evidencebased tools. Int J Equity Health. 2006;5:11.

5. Pinheiro RS, Travassos C. Estudo da desigualdade na utilização de serviços de saúde por idosos em três regiões da cidade do Rio de Janeiro. Cad Saude Publica. 1999;15(3):487-96.

6. Pinheiro RS, Viacava F, Travassos C, Brito AS. Gênero, morbidade, acesso e utilização de serviços de saúde no Brasil. Ciencia Saude Coletiva. 2002; 7(4):687-707.

7. Ballantyne P. The social determinants of health: a contribution to analysis of gender differences in health and illness. Scan J Public Health. 1999;27:290-5.

8. Cooper H. Investigating socio-economic explanations for gender and ethnic inequalities in health. Soc Sci Med. 2002;54:693-706.

9. Moss NE. Gender equity and socioeconomic inequality: a framework for the patterning of women's health. Soc Sci Med. 2002;54:649-61.

10. Silva PLN, Pessoa DGC, Lila MF. Análise estatística de dados da PNAD: incorporando a estrutura do plano amostral. Ciencia Saude Coletiva. 2002;7(4):659-70.

11. Pikhart H, Bobak M, Siegrist J, Pajak A, Rywik S, Kyshegyi J, et al. Psychosocial work characteristics and self rated health in four postcommunist countries. J Epidemiol Community Health. 2001;55:624-30.

12. Case A, Deaton A. Consumption, health, gender and poverty. Princeton: Princeton University; 2002.

13. Chandola T, Bartley M, Wiggins R, Schofield P. Social inequalities in health by individual and household measures of social position in a cohort of healthy people. J Epidemiol Community Health. 2003;57:56-62.

14. Almeida MF, Barata RB, Montero CV, Silva ZP. Prevalence of self reported chronic diseases and health services consumption from the National Household Sample Survey of 1998 in Brazil. Ciencia Saude Coletiva. 2002; 7(4):743-56.

15. Romero DE. Diferenciais de gênero no impacto do arranjo familiar no status de saúde dos idosos brasileiros. Ciencia Saude Coletiva. 2002;7(4):777-94

16. Denton M, Walters V. Gender differences in structural and behavioral determinants of health: an analysis of the social production of health. Soc Sci Med. 1999;48:221-35.

17. Matthews S, Manor O, Power C. Social inequalities in health: are there gender differences? Soc Sci Med. 1999;48:49-60.

18. Bartley M, Sacker A, Firth D, Fitzpatrick R. Social position, social roles and women's health in England: changing relationships 1984-1993. Soc Sci Med. 1999;48:99-115

19. Parkenson GR, Broadhead WE, Tse CJ. Health status and severity of illness as predictors of outcomes in primary care. Med Care. 1995; 33(1):53-66.

20. Costa JSD, Facchini LA. Utilização de serviços ambulatoriais em Pelotas: onde a população consulta e com que freqüência. Rev Saude $\mathrm{Pu}$ blica. 1997;31(4):360-9.

21. Mendonza-Sassi R, Béria JU Utilización de los servicios de salud: una revisión sistemática sobre los factores relacionados. Cuad Med Soc. 2001; 81:43-60.

22. Travassos C, Viacava F, Pinheiro R, Brito A. Utilização dos serviços de saúde no Brasil: gênero, características familiares e condição social. Rev Panam Salud Publica. 2002;11(5/6): 365-73.

23. Aquino EML, Menezes GMS, Amoedo MB. Gênero e saúde no Brasil: considerações a partir da Pesquisa Nacional por Amostra de Domicílios. Rev Saude Publ. 1992;26(3):195-202.

24. Kawachi I, Kennedy BP, Gupta V, ProthrowStith D. Women's status and the health of women and men: a view from the States. Soc Sci Med. 1999 48:21-32.

25. Krieger N. Genders, sexes, and health: what are the connections-and why does it matter? Int J Epidemiol. 2003; 32:6527.

Manuscript received 21 March 2006. Revised version accepted for publication 12 October 2006
RESUMEN

\section{Desigualdades de género y salud en adolescentes y adultos en Brasil, 1998}

\section{Palabras clave}

Objetivos. Evaluar la magnitud de las desigualdades de género con relación al estado de salud y la utilización de los servicios de salud en adolescentes y adultos en Brasil.

Métodos. Se tomó una muestra representativa compuesta por 217248 personas de 15 a 64 años de edad a partir de la Encuesta Nacional de Muestras de Hogares (Pesquisa Nacional de Amostras por Domicílios, PNAD), realizada por el Instituto Brasileño de Geografía y Estadísticas en 1998 con fondos del Ministerio de Salud. El estudio se concentró en tres variables de resultado (estado autoevaluado de salud, consultas médicas y hospitalizaciones (excepto para el parto)) y cinco variables de exposición (edad, sexo, origen étnico, ingresos y educación). Se utilizó la regresión logística incondicional y el análisis estratificado de Mantel-Haenszel. Se calcularon las razones de las tasas de prevalencia para cada estrato. Los intervalos de confianza se calcularon mediante la serie de Taylor, con un intervalo de confianza de 95\% (IC95\%).

Resultados. Las mujeres tuvieron una mayor probabilidad de considerar su salud regular o mala que los hombres (razón de posibilidades [odds ratio, OR]) =1,33; IC95\%: 1,31 a 1,35). Las desigualdades según el sexo fueron significativas para todas las edades y todos los niveles de ingresos del hogar y de educación, siempre desfavorables para las mujeres $(1,17 \leq$ $\mathrm{OR} \leq 1,44)$. Las desigualdades de género con relación a las consultas médicas fueron mayores en personas con buena salud; presentaron una tendencia a disminuir a medida que aumentaban la edad, los ingresos y el nivel educacional; y siempre estuvieron a favor de las mujeres $(1,12 \leq \mathrm{OR} \leq 2,06)$. Las desigualdades de género en cuanto a las tasas de hospitalización disminuyeron con la edad, fluctuaron de acuerdo con los ingresos y el nivel educacional en cada grupo de edad y siempre estuvieron a favor de las mujeres $(1,16 \leq \mathrm{OR} \leq 1,66)$. Conclusiones. Las diferencias en cuanto al estado autoinformado de salud en hombres y mujeres aumentaron después de ajustar por las variables socioeconómicas, lo que indica que las mujeres más pobres enfrentan mayores diferencias relativas que los hombres. El impacto de los factores determinantes estructurales, como la educación y los ingresos, es considerablemente menor que los elementos teóricos sociales de género, aunque los primeros son predictores más importantes. Las mujeres utilizan los servicios de salud con mayor frecuencia que los hombres, lo que es coherente con sus mayores necesidades de atención sanitaria. No obstante, las tasas de consultas médicas muestran una relación inversa con respecto a las necesidades de atención sanitaria, lo que indica que no es equitativo el acceso a la atención ambulatoria, especialmente a la atención preventiva.

Salud de la mujer, conducta de salud, accesibilidad a los servicios de salud, servicios de salud/utilización, estado de salud, Brasil. 